\title{
Akhlaq Learning Model in Al-Hidayah Islamic Boarding School for Girls
}

\author{
Sri Haningsih \\ Islamic Education Departement, \\ Islamic Studies Faculty \\ Islamic University of Indonesia \\ Yogyakarta, Indonesia \\ srihaningsih@uii.ac.id \\ Anisah Budiwati \\ Islamic Law Departement, Islamic \\ Studies Faculty \\ Islamic University of Indonesia \\ Yogyakarta, Indonesia
}

\begin{abstract}
This study aims to explore learning model of AlHidayah Islamic Boarding School for Girls. In the face of the education 4.0 era, Islamic boarding schools as an alternative choice of education among the low side of universities provide new offers to develop intellectual and moral character. The learning model applied in Islamic boarding schools provides santri with a learning experience in pursuing studies on campus. Using a qualitative approach, interviews, observations, and documentation of the Al-Hidayah Islamic Boarding School learning method were used, the results of the study were Islamic boarding school Al-Hidayah learning models combining education learning system 4.0 and salafi learning methods in Islamic boarding schools. This model is a prototype for Islamic boarding schools with santri who come from santri who are of various kinds of scientific undergraduate backgrounds.
\end{abstract}

Keywords- Akhlaq, Learning Model, Islamic Boarding School

\section{INTRODUCTION}

Elements of the learning process play a vital role in the teaching process [1]. Learning and teaching activities will only be meaningful if there are learning activities of students, so that the meaning of learning is modification or strengthening behavior through experience. From this understanding, learning is a process, an activity and not a result or goal. Learning not only remembers, but, more broadly than that, namely experiencing. Learning outcomes are not a mastery of the results of training but rather a change in behavior. In addition, there are also other interpretations of learning which state that learning is a process of changing individual behavior through interaction with the environment.

Regarding on [1] learning is a process of intellectual, spiritual development that is carried out continuously with certain approaches and methods so that humans have productive and ethical behavior. Learning, in the modern era, no longer has to stick to regularity and curriculum normativity. There needs to be renewal and innovation carried out by educators and policy makers in the context of educational politics. Educators, as knowledge transformers, need to understand in depth the aspects of psychology (learning) of students so that the ability of students to understand a problem is more comprehensive, so students have independence in solving each problem.
Furthermore, to create conditions and frequency of good learning, a learning style that is in accordance with the interests and abilities of students is needed. Learning style is one of the factors that influence student learning outcomes. Different ways or learning styles have an influence on student learning outcomes. Learning style is a strategy carried out by students in their learning to achieve the expected goals, namely good learning outcomes [2]. The learning objectives to be achieved must be optimal, for that there are several things that must be considered by educators, one of which is important that educators must know the type of style or learning style of students, so that educators can adjust what methods will be applied during teaching and teaching goals formulated by educators can be achieved.

The next question is how is the learning style applied in Islamic boarding schools with undergraduate students? Republic of Indonesia Government Regulation Number 55 of 2007 concerning Religious Education in article 26 concerning Islamic Boarding Schools that: (1) Islamic boarding schools carry out education with the aim of instilling faith and devotion to Allah SWT, having great morality, and the tradition of pesantren to develop participants' abilities, knowledge and skills students to become Islamic scholars (mutafaqqih fiddin) and / or become Muslims who have the skills / expertise to build an Islamic life in society, (2) pesantren conduct diniyah education or in an integrated manner with other types of education at the early childhood level, basic education, middle, and / or higher education, (3) students and / or in a boarding schools that are recognized for their expertise in the field of religion but do not have a formal education diploma can become educators of religious education subjects in all paths, levels and types of education after taking competency test according to regulation [3]. In addition, the demand for implementing the education system 4.0 is a challenge [4] to graduate an Islamic education institution.

Government regulations become jurisprudence for the implementation of education in Islamic boarding schools qualitatively, with methods and styles that must be adapted to culture and conditions. Islamic boarding schools at this time should be educational institutions that actively participate in creating academics and scientists who are qualified in their respective fields, rather than just the field of religion. Law 
enforcers must be clearly and historically elaborated, pesantren are recorded as consistent and committed to contributing graduates to create legal, educational, political, religious, and social products in the context of local wisdom.

Education in Islamic boarding schools is specific, supported by the ability of Kiai and other teaching staff to improve the quality of their students. This can be an opportunity for renewal and variation in determining the learning style, without removing the historical identity of the learning style in the pesantren, namely the sorogan and bandongan models. Even the fact that many students also choose Islamic boarding schools to broaden their knowledge. This phenomenon is commonly influenced by several Islamic Universities that implement a system of pesantrasiasi for new undergraduate students. The consequence of the issuance of this policy is the booming volumes of santri which must be balanced with the quantity and quality of the instructors, so that the pesantren's learning orientation in producing graduates who are able to have good morals.

Islamic boarding school education as a center for the development of human resources in order to have a goal of creating a better life and humanity. Islamic boarding schools as an institution that is identical with the meaning of indegenous Indonesia, religious (characterized by religion), and formally legalistic are recognized as part of a growing national education system [5]. Thus, based on these exposures, research related to the learning model in $\mathrm{Al}$ Hidayah Islamic Boarding School for Girls is needed. The significance of research that can be generated is the definition of learning models in Al-Hidayah Islamic Boarding School so that it can facilitate educators in delivering learning material.

\section{LITERATURE REVIEW}

Several previous studies that examined the learning model basically divided into several studies discussed. Research [6] with the tittle "Model Pembelajaran Instruksional di Pesantren Modern Daarul 'Uluum Lido". In the study, it was stated that the combination of the general (national) curriculum and the local curriculum (pesantren) was formulated in the modern pesantren learning model. This study uses a qualitative approach to describe the history and development of the Daarul 'Uluum Lido Modern Islamic Boarding School from the start of transforming traditional learning models into modern ones which include learning methods and curriculum. It was concluded that the main factor in the change in the implementation of the learning model in Islamic boarding schools was the composition of teaching staff who were mostly graduates from Islamic boarding schools who applied modern Islamic boarding school learning models.

Alvien Septian Haerisma's research about "Model Pembelajaran Bidang Ekonomi di Pondok Pesantren AlMizan Majalengka" (2016). This research explores the learning model in the economic field of Islamic economic review. The study used qualitative methods by collecting data on participant observation, in-depth interviews, and documentation. The application of learning models conducted at Al-Mizan Islamic Boarding School uses participatory, active, creative, effective and fun learning patterns (called by PAKEM). The application of contextual learning models in the field of economics in Islamic boarding schools by means of active learning designed by Al-Mizan Foundation [7].
Research [8] with the tittle "Tipologi Perubahan dan Model Pendidikan Multikultural Pesantren Salaf". This research shows that it is very difficult to say that there are still traditional (salaf) pesantren in the world of education, because the current model is a mixture of traditional and modern styles, the salafis take the basic principle of "keeping the old and the good and taking the new for good ". This model is considered to be in accordance with Indonesian culture which is diverse in terms of religion and ethnicity, where Islam is meant to be friendly, moderate, and tolerant.

Research that explores the differences in figh learning methods in Islamic boarding schools, madrasah, and schools. He gives similarities between Islamic boarding schools and madrassas because historically pesantren are the oldest Islamic institutions in Indonesia. The difference in fiqh teaching systems in three institutions depends on each characteristic of each institution. In Islamic boarding schools, fiqh is taught by a non-classical system. The learning of fiqh is based on the holly book of fiqh (kutub turats) that are not regulated in the programmed syllabus, while in madrasah, fiqh is a separated subject from a clump of Islamic Religious Education (PAI), while at schools, fiqh is an integral part of the subjects if PAI [9].

Research [10] which revealed that Islamic boarding schools are educational institutions that can act as models of character education in Indonesia. This research examines the strategies and patterns of character education applied by pesantren to form sub-cultures. This study focused on two Islamic boarding schools namely the Langitan Boarding School in Tuban and the Ihyaul Ulum Gilang Islamic Boarding School by using qualitative research. The factors that support the success of the second character education in Pondok Pesantren are at least three main things, namely the figure of Kiai, the intensity of continuous interaction between santri and mentors, and the existence of rules and regulations that are elaboration of Kiai's ideals with the pesantren's vision.

Paper about the construction of the pesantren curriculum in a model and learning method approach [11]. This paper examines the learning theory applied in carrying out the value system tends to use behavioristic which encourages students to be obedient to the existing value system, but in the learning process such as bandongan, wetonan, sorogan mudzakarah, muhadatsah emphasizes constructive learning which does not require santri to understand certain disciplines. While in the mental learning Islamic boarding school leads to humanistic education where students are taught to be aware of their position as creatures of Allah and servants who have the duty to worship.

Undergraduate research with a quantitative approach related to Al-Hidayah Islamic Boarding School was written by Lisnawati. The results of the study state that there is an influence of Islamic Education on Morals in Al-hidayah Islamic boarding schools for Girls in Candikarang Sleman Yogyakarta and the influence of habituation to Islamic education on morals in Al-Hidayah Islamic boarding schools for Girls in Candikarang Sleman Yogyakarta.

Based on the studies mentioned above, nothing has substantially presented the Student Islamic Boarding School learning model specifically. Therefore, the significance of the author's research has a different dimension from the previous studies. The study of the santri learning model in the pesantren 
is an interesting object to be studied in depth, especially $\mathrm{Al}$ Hidayah Islamic boarding school for Girls.

\section{METHODOLOGY}

The type of research that will be conducted by researchers is qualitative research. This research was conducted to reveal the distinctive characteristics and learning models of $\mathrm{Al}$ Hidayah Islamic Boarding School Candikarang Sardonoharjo Ngaglik Sleman Special Region of Yogyakarta. This objective is in line with the understanding of qualitative research proposed by Idrus and Sugiyono. Qualitative research according [12] namely research where researchers examine informants as the subject of research in their daily living environment. While [13] defined as research used to examine natural objects where researchers as key instruments, data samples were carried out purposively and snowbally, data collection techniques with triangulation, data analysts were inductive, and research results emphasized meaning.

Data analysis techniques in this study use content analysis, in this case the Al-Hidayah Islamic Boarding School includes history, learning processes and activities. The mechanism of content analysis is: 1) data collection is a process of data collection related to research, 2) data reduction is data obtained from the field needs to be researched and detailed again, 3) data presentation is a process carried out after reducing data that is often realized in the form of brief descriptions, charts, relationships between categories, flowcharts, and the like, and 4) verification is the process of drawing conclusions.

\section{RESULTS AND DISCUSSION}

\section{A. Identity of Al-Hidayah Islamic Boarding School for Girls}

Islamic Boarding Schools which were inaugurated on 17 Ramadhan 1436 H / 4 July 2015 M is an institution under the care of Dhiyaul Ashrof Srigita Foundation. Al Hidayah is an Islamic educational institution that seeks to develop and combine the learning of universities and Islamic boarding schools that both have an objective that must be achieved integrally, namely the development of a balance of intellectual potential of learning the world and the hereafter by promoting excellent character. Efforts between intellectual development and the application of excellent personalities are carried out continuously and istiqomah for the purpose of a happy life in the world and the hereafter

The effort to realize this is in a vision that is the realization of a conducive, quality pesantren to produce Islamic leaders with religious knowledge, scientific deeds and moral character in 2028 and their mission, namely; 1) organizing learning in an Islamic environment, integrated boarding school quality management perspective curriculum rahmatan lil'alamiin and ulil albab, 2) preparing prospective nation leaders who are tafaqquh fiddin (religious ideas correctly according to the Qur'an and Hadith), honest, intelligent broad-minded and responsible.

This boarding school is supported by supporting facilities, namely 1) santri dormitories that are representative and conducive environment (parking on the 1 st floor, bedrooms on the 2nd floor and multi-purpose meeting rooms, and prayer rooms, 3-bedroom floors), 2) Meeting rooms development of scientific insights through workshops, scientific discussions,
Islamic religious studies and libraries, 3) availability of wifi, LCD, and screenview for learning innovations.

From the style and typology of Islamic boarding schools, the characteristics and peculiarities of each pesantren, the pesantren is included in the pesantren that develops a characteristic as an Islamic education institution that encourages the balance of the intellectual potential of the world and the hereafter by promoting noble character. The pesantren consists of santri conditions which vary greatly from the fields of statistics, pharmacy, chemistry, medicine, chemistry education, international relations, English, management economics, informatics, and the majority of the Islamic Faculty in general. Thus this Islamic boarding school has a concept that combines intellectual and noble personality through environmental aspects and the design of its educational curriculum.

As an Islamic education institution, this pesantren has a distinctive curriculum which combines two things:

1) The value of leadership is obtained by studying :

a) the quran and its interpretation; learn quranan grammar by discussing the word per word in the Qur'an by utilizing the website corpus.quran.com

b) Hadith (Shahih Bukhori and Hadith Tarbawi); the hadith which are the sunnah of the Prophet Muhammad were memorized and studied especially those related to the morality of everyday life

c) Moral aqidah; the santri learns about the asthma and its implementation, interpreting each verse and its meaning

d) Kitab kuning; students were invited to be able to translate and understand the book of pesantren such as the Fathul Qorib to know the procedures for purification, prayer, zakat, etc.

e) Contemporary fiqh studies; santri study the latest issues related to fiqh that exist at this time, fiqh for female especially fiqh thaharah.

2) Development of self potential through

a) Independence; obtained by giving the task of arranging campus activities with a schedule of joint recitations at the Pesantren. Prayers in congregation are on time and there is also a scheduled cleaning schedule every week so that students are required to discipline what they are responsible for.

b) Interest and talent; obtained by giving the opportunity to all students to develop their interests and talents both in terms of entrepreneurship and academics.

c) Life skill; santri are given social skills to be able to interact with other santri, get to know characters and be asked to solve social problems that exist between them. The teacher of the Koran was asked by the community, the assistant lecturer at the study program

d) Foreign language (Arabic and English); students are given motivation and language learning to 
support the ability to read, listen and speak in foreign languages.

e) Public speaking (muhadloroh); the students were asked to make a mau'idhah hasanah to the majlis ta'lim in the community so that their public speaking skills were honed.

Thus as the purpose of education carried out in this Islamic Boarding School is 1) realizing a conducive environment for learning, optimizing the potential of santri so that competency maturity is achieved tafaqquh fiddin (naqliyyah / aqliyyah), 2) implementing an integrated quality management system and perspective Action (PDCA), and 3) conduct internal monitoring and evaluation (monev-in) in the framework of amar ma'ruf nahi munkar. The overall objectives of the pesantren are like the four pillars formulated by UNESCO namely learning to know (learning to know), learning to do (learning to work), learning to live together (learning to live together) and learning to be (learning to develop in full) [14].

\section{B. Learning Model: Combination of Education 4.0 and Salafi Islamic Boarding School}

According to [15] there are three analyzes that are used to look at the learning process carried out in one educational institution namely learning approaches, learning strategies, and learning methods. The learning approach referred to in this study is the starting point of the learning process which includes two approaches, namely student-centered approach and teacher-centered approach. While the learning strategy in this study is a form of learning activities undertaken by teachers and students to achieve learning objectives effectively and efficiently. Then the learning method is the method used to implement plans that have been prepared in the form of real and practical activities.

The learning process of Al-Hidayah Islamic Boarding School can be explained in the following three points, namely:

1. The learning approach used in this institution is centered on two approaches. Learning is centered on students (student centered approach), which uses group learning that encourages active participation of every santri. In daily activities the santri are given the responsibility to look for a hadith then give it to their friends in whatsup group to comment on their friends. In addition, a teacher-centered approach is used through religious studies and other spiritual activities such as the dawn study.

2. Learning strategies used in learning in Islamic Boarding Schools combine intellectual and noble personality. The intellectual side of student santri was obtained from the material delivered by the counselor covering 3 things namely fiqh, morals, and language. While noble moral personality is developed through daily activities to apply Islamic attitudes.

3. The learning method that is carried out in this pesantren is contextual learning. In addition, cooperative learning methods are used, where santri work together to learn and are responsible for the progress of their learning, both individually and in groups. [16]. In learning, there is a communication process so that santri can remind each other and give advice, so that the participation of santri who interact with each other is built, increasing the performance of santri in completing Islamic boarding school assignments. Apart from cooperative learning learning methods, contextual learning models are also used in the form of conceptions that help teachers associate material content with real world situations and motivate santri to make connections between knowledge and its application in their lives as part of society. Santri is invited to be able to link the material of fiqh, morals, and language in everyday life.

From the typology of the pesantren that was formulated [10] Al-Hidayah Islamic Boarding School are included in the category of khalafiyah (modern) where the Islamic sciences and general science are taught, especially language skills and public speaking. But in terms of the learning method used, this pesantren is also said to use a mixed method. If [17] used the book reading method with the activity of santri, in this pesantren the mixture used is using modern methods namely e-learning, so that santri can also read and deliver via social media such as classroom menus on google accounts of every santri. Santri is given internet facilities as a learning media to seek additional knowledge as well as a means of building communication between santri and teachers.

In line [18] said that integration and interconnection are the hallmark of Islamic education, the combination of Islamic Boarding Schools in combining Education 4.0 and Salafi Islamic Boarding Schools is translated through the integration between santri's intellectual and noble character. This is based on current digital conditions that require the right environment. Environment that supports learning [14] such as the atmosphere of reciting and reading through e-learning, control and togetherness with the teacher can provide positive support for the development of santri learning.

Education 4.0 is self-determined learning because it has entered the Industrial Revolution 4.0 era, while education 1.0 is pedagogy learning that learning of young children, has not understood the transformation process, 2.0 education namely andragogy learning, adult learning, education 3.0 namely adult learning using mobile learning, [19]. Therefore the Islamic Boarding School of Al-Hidayah provides learning models that not only use face-to-face, but are modified with elearning and learning that uses software for example understanding the grammar of the Qur'an.

In addition to using education 4.0 learning system, this pesantren also uses a salafi model. If we see the meaning of salafi in general it will be different from what is applied by this pesantren. The meaning of salafiyah referred to by the pesantren as it is [10] namely Islamic boarding schools that only teach Islamic religious sciences or classical books written by the previous scholars with the methods of teaching bandongan, sorogan, memorization and deliberation. Other meanings [20] referring to the meaning of traditional Islamic boarding schools, namely pesantren which always preserve past traditions, as a term that shows the general and dominant meaning to refer to the notion of continuity of tradition originating from local indigenous people. Then as [17] traditional Islamic boarding schools are reinforced by elements such as Kiai, santri, dormitories, mosques, kitab kuning and what is not less important is the religious ideology of ahlussunnah wal jamaah adopted by the pesantren. To 
strengthen the use of books with typical salafi methods such as sorogan, lecture or other.

The elaboration of the meaning of salafi today, the Leaders of Islamic Boarding Schools formulate that the salafi values used by Islamic boarding schools are salafi meanings which refer to Qs. Al-Qashah verse 77. This letter describes the importance of the balance of the world and the hereafter. Some of the values extracted from the verse are orders to think of the afterlife by mastering the religious sciences, but not forgetting to be balanced with world affairs by thinking about what needs to be done, the command to do good to others and not doing damage in advance Earth. Thus, santri have more value than those who do not study at Islamic Boarding Schools.

In the learning process, Islamic boarding schools use a particular form of curriculum that is used, namely complete teaching of the book learned (kitabi) based on the handbook as the main reference so that the end of the learning system provided by Islamic boarding schools has a standard upon completion of the books studied [11], but this is different from the al-Hidayah Islamic Boarding School which is not only the completion of the book, but it reaches the level of the santri' understanding in applying daily morality.

The learning model used in Al-Hidayah Islamic Boarding Schools for Girls can be explained by understanding five dimensions [21] as follows :

1. Information that can be received by santri relates to sensory namely vision, sound, physical. This is often found when the learning process is carried out together and the santri performs vision and hearing, such as seeing how language learning understands the book of figh thaharah women are taught to practice and together listen to the explanation of the book to understand its meaning

2. The most effective sensory information felt by santri is visually both with diagrams, images, graphics, verbal, and demonstrations. Demonstrations were exemplified by language teachers in public speaking and verbal material exemplified when caregivers gave meaning to reading books and advice

3. Santri actively processes information through his involvement in tadarus activities, reading the name of the Prophet, praying in congregation, praying, and other physical activities

4. Santri achieves progress towards understanding sequentially with small steps. Santri are given the task of managing their respective activities and are asked to fill in their respective quality control forms

5. In the arrangement of information, the santri feels most comfortable in a deductive way, namely the great principles are given, then the consequences are sought and the application, then conclusions are drawn.

In an effort to develop emotional intelligence, especially in moral learning as formulated [22] Islamic boarding schools provide several points as follows :

1. Providing a conducive environment; where Islamic boarding schools provide learning media facilities that make it easy without losing control of the teacher.
2. Creating a democratic learning climate; where the availability of discussion forums to develop the interests and talents of each santri such as for entrepreneurship or teaching

3. Develop empathy; santri are invited to learn to pray for their parents, teachers and Muslims in order to feel the bonding unity as brothers

4. Helping santri find solutions to the problems they face; given the opportunity to interact socially with other santri so that they are smart to find solutions

5. Involve santri optimally in learners both physically, socially and emotionally; santri are invited to socialize with the community around the Pondok such as recitation, community service or in large events such as the Mawlid Nabi or Santri Day

6. Respond positively to the behavior of santri and avoid negative responses; The cottage environment encourages the attitude of santri not to be negative, such as prioritizing personal interests

7. Be an example for santri; The cottage environment, especially teachers, is a good example in daily life.

So, Islamic boarding schools have a paradigm that santri in principle are adult humans who have independence which is indicated they can manage their own time. But Islamic boarding schools provide soft skills that are not obtained at universities such as:

1. Personal qualities, such as responsibility, selfconfidence, social skills, management (control) self, and integrity or honesty

2. Interpersonal skills, such as participating as group members, teaching or sharing knowledge to others, serving customers, leadership, negotiating skills, and being able to work in diversity.

Thus, in the current era of disruption, pesantren guard the moral values that should be present in the next generation that will become leaders in this country. The cultural existence of the pesantren and the existing global developments encourage the realization of Islamic boarding schools that wisely build dimensions of Islam, Indonesianness (locality) and science [23].

\section{CONCLUSION}

The Islamic boarding school education system by combining education 4.0 learning system with the salafi system of Islamic boarding schools can be a solution to the learning model of Islamic Boarding Schools in the digital era. The ease of knowledge gained from internet information technology still requires escorting the system from the existence of leader control and the rules of the Pondok. Islamic boarding schools become an alternative when the school education system or university is considered to have many weaknesses. Therefore a new trend that is with the combination of education learning system model 4.0 with the salafi system of Islamic boarding schools provides positive support for the development of student learning. Even so, even though the pesantren has tried to guard the moral aspects, it still requires an achievement strategy in the form of techniques and methods that are in line with the 
achievement of the educational goals of Al-Hidayah Islamic Boarding School.

\section{REFERENCES}

[1] O. Hamalik, Proses Belajar Mengajar, Cet. XII. Jakarta: PT Bumi Aksara, 2011.

[2] S. Nasution, Didaktik Asas-Asas Mengajar. Jakarta: Bumi Aksara, 2003.

[3] Nurkholis, Santri Wajib Belajar. Purwokerto: STAIN Purwokerto Press, 2015.

[4] A. W. Maktub, "Membangun Akhlak Karimah dalam Era Education 4.0," 2017.

[5] F. A. Aziz, Manajemen Pesantren: Paradigma Baru Mengembangkan Pesantren. Purwokerto: STAIN Purwokerto Press, 2014.

[6] R. Abdillah, O. Abdurakhman, and N. Maryani, "Model Pembelajaran Instruksional di Pesantren Modern Daarul 'Uluum Lido," Tadbir Muwahhid, vol. 2, no. 1, pp. 46-59, 2018.

[7] A. S. Haerisma, "Model Pembelajaran Bidang Ekonomi di Pondok Pesantren Al-Mizan Majalengka," Al Amwal, vol. 8, no. 1, 2016.

[8] Marzuki, Miftahuddin, and M. Murdiono, "Tipologi Perubahan dan Model Pendidikan Multikultural Pesantren Salaf," Yogyakarta, 2010.

[9] M. Athoillah, "The Methods of Teacing and Learning Fiqh in Islamic Boarding School, Islamic School and Public School,” J. Pendidik. Islam, vol. 2, no. 1, 2015.

[10] M. S. Zuhriy, "Budaya Pesantren dan Pendidikan Karakter pada Pondok Pesantren Salaf," Walisongo, vol. 19, no. 2, pp. 287-310, 2011.
[11] Suheri, "Konstruksi Kurikulum Pesantren dalam Pendekatan, Model dan Metode Pembelajaran,” J. Appl. Linguist. anda Islam. Educ., vol. 01, no. 01, pp. 133-145, 2017.

[12] M. Idrus, Metode Penelitian Ilmu Sosial. Jakarta: Erlangga, 2009.

[13] Sugiyono, Metode Penelitian Pendidikan Pendekatan Kuantitatif, Kualitatif, dan R\&D. Bandung: Alfabeta, 2013.

[14] N. S. Sukmadinata, Landasan Psikologi Proses Pendidikan, Cet. ke 5. Bandung: PT Remaja Rosdakarya.

[15] M. Sholeh, Metodologi Pembelajaran Kontemporer. Yogyakarta: Kaukaba Dipantara, 2014

[16] Trianto, Mendesain Model Pembelajaran Inovatif-Progresif: Konsep, Landasan dan Implementasinya pada Kurikulum Tingkat Satuan Pendidikan (KTSP), 6th ed. Jakarta: Kencana Prenada Media Group, 2009.

[17] A. Zuchairiny, "Penguatan Islam Tradisional: Studi Kasus Model Pembelajaran Kitab Kuning di Pesantren Alkhairaat Madinatul Ilmi Dolo Sulawesi Tengah," ISTIQRA, vol. 1, no. 2, 2013.

[18] Rohinah, "Filsafat pendidikan Islam; Studi Filosofis atas Tujuan dan Metode Pendidikan Islam,” J. Pendidik. Islam, vol. 2, no. 2, p. 309, 2014.

[19] A. S. Jahja, "Pendidikan 4.0 (Heutagogy)," 2018. [Online]. Available: https://dosen.perbanas.id/pendidikan-4-0-heutagogy/.

[20] A. Mughits, Kritik Nalar Fiqh Pesantren. Jakarta: Kencana, 2008.

[21] D. Indriana, Mengenal Ragam Gaya Pembelajaran Efektif. Yogyakarta: Diva Press, 2011.

[22] N. H. Rofiah, "Desain Pengembangan Pembelajaran Akidah Akhlak di Perguruan Tinggi," Fenomena, vol. 8, no. 1, p. 56, 2016.

[23] Mukhibat, "Meneguhkan Kembali Budaya Pesantren dalam Merajut Lokalitas, Nasionalitas dan Globalitas," KARSA (Jurnal Sos. dan Budaya Keislaman), vol. 23, no. 2, 2015 